Grzegorz KOWALECZKO, Krzysztof GRAJEWSKI, Szymon KOBIELA, Romuald KAŹMIERCZAK

Air Force Institute of Technology (Instytut Techniczny Wojsk Lotniczych)

\title{
THE IMPACT OF STANDARD DEVIATION OF WIND ON THE BOMB FLIGHT IN ATMOSPHERIC TURBULENCE
}

\author{
Wpływ odchylenia standardowego wiatru na lot bomby \\ w atmosferze turbulentnej
}

\begin{abstract}
The paper provides the simulation results of a small-diameter guided training bomb released during atmospheric turbulence. The simulation utilized a guided bombed devised at ITWL. Aerodynamic characteristics of the bomb were obtained from wind tunnel tests and from calculations made by the PRODAS programme. The simulation programme was developed based on a mathematical model describing a spatial motion of an aerial bomb moving in atmospheric turbulence. To describe a turbulence component, the model of stochastic processes proposed by Shinozuki was used. The manuscript includes examples of diagrams of basic parameters showing the bomb flight in a disturbed atmosphere. The analysis of the impact of the standard deviation of the wind on the change in the parameters of bomb flight was performed. The relationships between the parameters of bomb flight and the possibility to hit the target were provided.
\end{abstract}

Keywords: bomb, numerical simulation, turbulence of the atmosphere

Streszczenie: $W$ artykule przedstawiono wyniki symulacji lotu ćwiczebnej bomby kierowanej małego wagomiaru zrzuconej w warunkach atmosfery turbulentnej. Do symulacji użyto bomby kierowanej zaprojektowanej w ITWL. Charakterystyki aerodynamiczne bomby otrzymano z badań $w$ tunelu aerodynamicznym i obliczeń wykonanych $w$ komercyjnym programie PRODAS. Program symulacyjny opracowany zostat na podstawie modelu matematycznego opisujacego ruch przestrzenny bomby lotniczej poruszajacej się $w$ warunkach turbulentnej atmosfery. Do opisu składowej turbulencji wykorzystano model procesów stochastycznych zaproponowany przez Shinozukiego. W artykule pokazano przykładowe przebiegi podstawowych parametrów opisujących lot bomby w zaburzonej atmosferze. Dokonano analizy wpływu odchylenia standardowego wiatru na zmiane parametrów lotu bomby. Przedstawiono zależności występujace między parametrami lotu bomby a możliwościa trafienia $w$ cel.

Słowa kluczowe: bomba, symulacja numeryczna, turbulencja atmosfery 


\section{Introduction}

The conditions at the modern theatre of military operations increase the requirements concerning weapons and methods of its application. Results from analysing modern military conflicts show that the number of aerial weapons needed to demolish the selected targets is on the decrease as well as the number of aircraft needed to perform particular tasks. The bombs still remain the most important aerial weapons of combat aviation intended for operations aimed at destructing the ground targets. During the operation called 'Desert Storm', the unguided bombs constituted $93 \%$ of all weapons dropped by the ally's aeroplanes [1]. The bomb should be released in such a way as to hit the target. Conditions during the release can change due to the change in the flight state of the aircraft. The primary output parameters of a bomb are comprised of initial speed, bomb release altitude and release angle. Besides, the path of the bomb's flight is also affected by the disturbance of the atmosphere in the form of turbulence and wind speed.

The manuscript addresses the influence of the standard deviation of the wind on the bomb's flight. Flight phases of a guided bomb were shown, taking into consideration the standard deviation of the wind. The possibility of a bomb reaching the target was analysed with a sufficiently large angle of fall. The analysis of the impact on the tested object was carried out by numerical simulation. The basic requirement of reliable results is to include in modelling reliable aerodynamic and mass characteristics. In the discussed case, we obtained aerodynamic characteristics of a tested bomb using the PRODAS programme and based on the results of the wind tunnel tests. A significant element of simulation is the model of wind which was adopted for calculations. It assumes that the wind speed is a random time function $t$ and location in space. The instantaneous values of wind components in the Earth-fixed system Oxgygzg equal the sum of its average values and additional variables during fluctuation. This model was described by Shinozuki [7].

\section{Assumptions adopted in the analysis of the dynamics of the bomb's movement}

To analyse the dynamics of the bomb's movement, the following assumptions were adopted:

a) a bomb is a solid body with a constant mass, inertial moments and unchangeable location of the centre of the mass

b) a bomb is a rigid mechanical system with 6-DOF;

c) body of the bomb is axisymmetrical;

d) planes of geometrical, mass and aerodynamic symmetry are Oxy and Oxz planes. 


\section{Coordinate systems and its transformation}

Coordinate systems applied to describe the movement of a bomb in atmospheric turbulence and their matrixes, were exhibited in table $1[2,3]$.

Table 1

\section{Coordinate systems}

\begin{tabular}{|c|c|c|}
\hline \multicolumn{3}{|c|}{ Rectangular coordinate systems } \\
\hline Oxyz - body system & $\begin{array}{l}O x_{a} y_{a} z_{a} \text { attached air-trajectory } \\
\text { system }\end{array}$ & $O x_{g} y_{g} z_{g}$ Earth-fixed system \\
\hline \multicolumn{3}{|c|}{ Transformations of rectangular coordinate systems } \\
\hline transformations of systems & $\begin{array}{l}\text { transformation angles } \\
\text { between systems }\end{array}$ & transformation matrix \\
\hline$O x y z$ and $O x_{g} y_{g} z_{g}$ & $\begin{array}{c}\text { angle of yaw } \Psi, \\
\text { angle of pitch } \Theta, \\
\text { angle of roll } \Phi .\end{array}$ & {$\left[\begin{array}{l}x \\
y \\
z\end{array}\right]=\mathrm{L}_{\mathrm{b} / \mathrm{g}}\left[\begin{array}{l}x_{g} \\
y_{g} \\
z_{g}\end{array}\right]$} \\
\hline \multicolumn{3}{|c|}{$\begin{array}{l}\text { where: } \\
\qquad L_{b / g}=\left[\begin{array}{ccc}\cos \Psi \cos \Theta & \sin \Psi \cos \Theta & -\sin \Theta \\
\cos \Psi \sin \Theta \sin \Theta-\sin \Psi \cos \phi & \sin \Psi \sin \Theta \sin \phi+\cos \Psi \cos \phi & \cos \Theta \sin \phi \\
\cos \Psi \sin \Theta \cos \phi+\sin \Psi \sin \phi & \sin \Psi \sin \Theta \cos \phi-\cos \Psi \sin \phi & \cos \Theta \cos \phi\end{array}\right]\end{array}$} \\
\hline$O x y z$ and $O x_{a} y_{a} z_{a}$ & $\begin{array}{cc}\text { sideslip angle } & \beta, \\
\text { angle of attack } & \alpha .\end{array}$ & {$\left[\begin{array}{l}x \\
y \\
z\end{array}\right]=L_{\mathrm{b} / \mathrm{a}}\left[\begin{array}{l}x_{a} \\
y_{a} \\
z_{a}\end{array}\right]$} \\
\hline$L_{b / a}=$ & $\begin{array}{ccc}\operatorname{os} \alpha \cos \beta & -\cos \alpha \sin \beta & -\sin \\
\sin \beta & \cos \beta & 0 \\
\sin \alpha \cos \beta & -\sin \alpha \sin \beta & \cos \alpha \\
\end{array}$ & \\
\hline
\end{tabular}

\section{Equations of movement of the guided bomb}

Equations of movement of the bomb were specified in the non-inertial coordinate bomb-fixed $(O x y z)$ system. It regards both translational and rotational motion [4].

Table 2

\section{Equations of movement of the bomb}

\begin{tabular}{|c|c|c|c|}
\hline \multicolumn{4}{|c|}{ Equations of translational motion } \\
\hline $\begin{array}{l}\text { Vector equations of } \\
\text { translational motion of the } \\
\text { centre of mass }\end{array}$ & $\begin{array}{l}\text { vectors: li } \\
\text { speed and }\end{array}$ & $\begin{array}{l}\text { ar speed, angular } \\
\text { xternal forces }\end{array}$ & $\begin{array}{l}\text { scalar equations in the } O x y z \\
\text { coordinate system }\end{array}$ \\
\hline$\frac{d(m V)}{d t}=\frac{ð(m V)}{ð t}+\mathbf{\Omega} \times(m \mathbf{V})=\mathbf{F}$ & $\mathbf{V}=\left[\begin{array}{c}U \\
V \\
W\end{array}\right]$ & $\mathbf{\Omega}=\left[\begin{array}{l}P \\
Q \\
R\end{array}\right], \quad \mathbf{F}=\left[\begin{array}{l}F_{x} \\
F_{y} \\
F_{z}\end{array}\right.$ & $\begin{array}{l}m(\dot{U}+Q W-R V)=F_{x} \\
m(\dot{V}+R U-P W)=F_{y} \\
m(\dot{W}+P V-Q U)=F_{z}\end{array}$ \\
\hline \multicolumn{4}{|c|}{$\begin{array}{l}\text { where: } \\
m \text {-mass of a bomb; } \\
\text { vectors: V-absolute linear speed, } \mathbf{\Omega} \text { - angular speed, F- external forces; } \\
U, V, W \text {-vector components of linear speed } \mathbf{V} ;\end{array}$} \\
\hline
\end{tabular}




\begin{tabular}{|c|c|c|}
\hline \multicolumn{3}{|c|}{$P, Q, R$-vector components of angular speed $\boldsymbol{\Omega}$. } \\
\hline \multicolumn{3}{|c|}{ Equations of rotational motion } \\
\hline $\begin{array}{l}\text { vector equation of rotational } \\
\text { movement }\end{array}$ & angular momentum vector & $\begin{array}{l}\text { scalar equations in the } O x y z \\
\text { coordinate system }\end{array}$ \\
\hline$\frac{d(\boldsymbol{K})}{d t}=\frac{\partial(\boldsymbol{K})}{\partial t}+\mathbf{\Omega} \times \mathbf{K}=\mathbf{M}$ & $\begin{array}{c}\mathbf{K}=\mathbf{I} \cdot \mathbf{\Omega} \\
\text { where: } \\
\mathbf{I}=\left[\begin{array}{ccc}I_{x} & -I_{x y} & -I_{x z} \\
-I_{y x} & I_{y} & -I_{y z} \\
-I_{z x} & -I_{z y} & I_{z}\end{array}\right] \\
I_{x y}, I_{y x}, I_{z y}, I_{y z}, I_{z y}, I_{y z}=0\end{array}$ & $\begin{array}{c}\dot{P}=\frac{1}{I_{X}} L \\
\dot{Q}=\frac{1}{I_{y}}\left[M+P R\left(I_{x}-I_{z}\right)\right] \\
\dot{R}=\frac{1}{I_{z}}\left[N+P Q\left(I_{y}-I_{x}\right)\right]\end{array}$ \\
\hline \multicolumn{3}{|c|}{$\begin{array}{l}\text { where: } \\
\text { I-tensor of the moments of inertia; } \\
L, M, N \text {-components of moments of aerodynamic forces } \mathbf{M} \text {. }\end{array}$} \\
\hline \multicolumn{3}{|c|}{ Kinematic relationships } \\
\hline \multicolumn{3}{|c|}{$\begin{array}{c}\dot{\Phi}=P+(R \cos \Phi+P \sin \Phi) \operatorname{tg} \Theta \\
\dot{\Theta}=Q \cos \Phi-R \sin \Phi \\
\dot{\Psi}=(R \cos \Phi+Q \sin \Phi) \frac{1}{}\end{array}$} \\
\hline \multicolumn{3}{|c|}{ Vector of flight parameters } \\
\hline \multicolumn{3}{|c|}{$\mathbf{x}(\mathrm{t})=\left[U, V, W, P, Q, R, \Phi, \Theta, \Psi, x_{g}, y_{g}, z_{g}\right]$} \\
\hline $\begin{array}{l}\text { where: } \\
x_{g}, y_{g}, z_{g} \text { - coordinates of the }\end{array}$ & in the inertial $O x_{g} y_{g} z_{g} \mathrm{~s}$ & \\
\hline
\end{tabular}

\section{Determining aerodynamic forces and moments}

\subsection{Bomb speed relative to the air}

To calculate aerodynamic forces, we need to know the bomb speed relative to air $\mathbf{V}_{a e r}=\left[U_{a e r}, V_{a e r}, W_{a e r}\right]^{\mathrm{T}}$. This speed is equal to the difference of speeds relative to the inertial system $\mathbf{V}$ and the speed of wind $\mathbf{V}_{w}=\left[U_{w}, V_{w}, W_{w}\right]^{\mathrm{T}}$ relative to the same system $[4,5]$.

\section{Table 3}

\section{Bomb speed relative to the air}

\begin{tabular}{|c|c|}
\hline \multicolumn{2}{|c|}{ Bomb speed relative to the air } \\
\hline $\mathbf{V}_{a e r}=\mathbf{V}-V_{w}$ & $\begin{array}{c}\mathbf{V}_{a e r}=\left[U_{a e r}, V_{a e r}, W_{a e r}\right]^{\mathrm{T}} \\
\mathbf{V}_{w}=\left[U_{w}, V_{w}, W_{w}\right]^{\mathrm{T}}\end{array}$ \\
\hline \multicolumn{2}{|c|}{$\begin{array}{l}\text { where: } \\
\mathbf{V}_{a e r} \text { - bomb speed relative to the air; } \\
\mathbf{V}_{w} \text { - wind speed; } \\
\mathbf{V} \text { - speed relative to the inertial system; } \\
U_{a e r}, V_{a e r}, W_{a e r} \text { - speed components of the bomb relative to the air; } \\
U_{w}, V_{w}, W_{w} \text {-speed components of the wind }\end{array}$} \\
\hline Angle of attack & \\
\hline
\end{tabular}




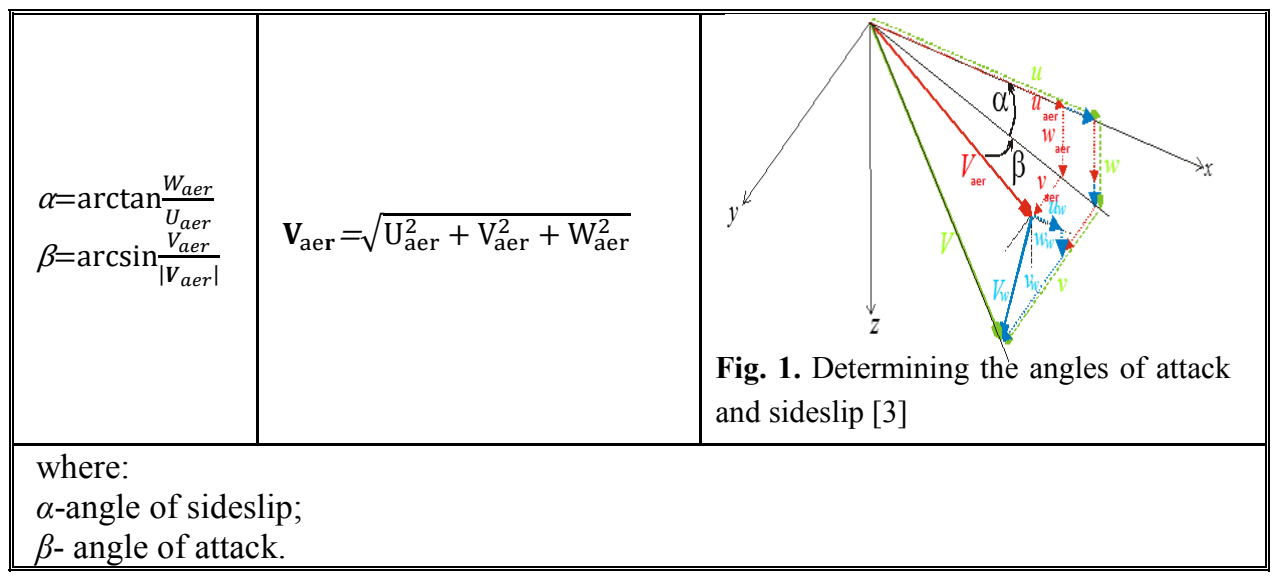

\subsection{Forces acting on the bomb}

The bomb in motion is influenced by the following forces: aerodynamic and gravitational force. Gravity force $\mathbf{Q}$ and aerodynamic force $\mathbf{R}$, which has three components $\mathbf{R}=\left[R_{x_{a}}, R_{y_{a}}, R_{z_{a}}\right]^{\mathrm{T}}$ in the air-trajectory $O x_{a} y_{a} z_{a}$ reference frame $[6,9]$.

\section{Forces acting on the bomb}

\section{Table 4}

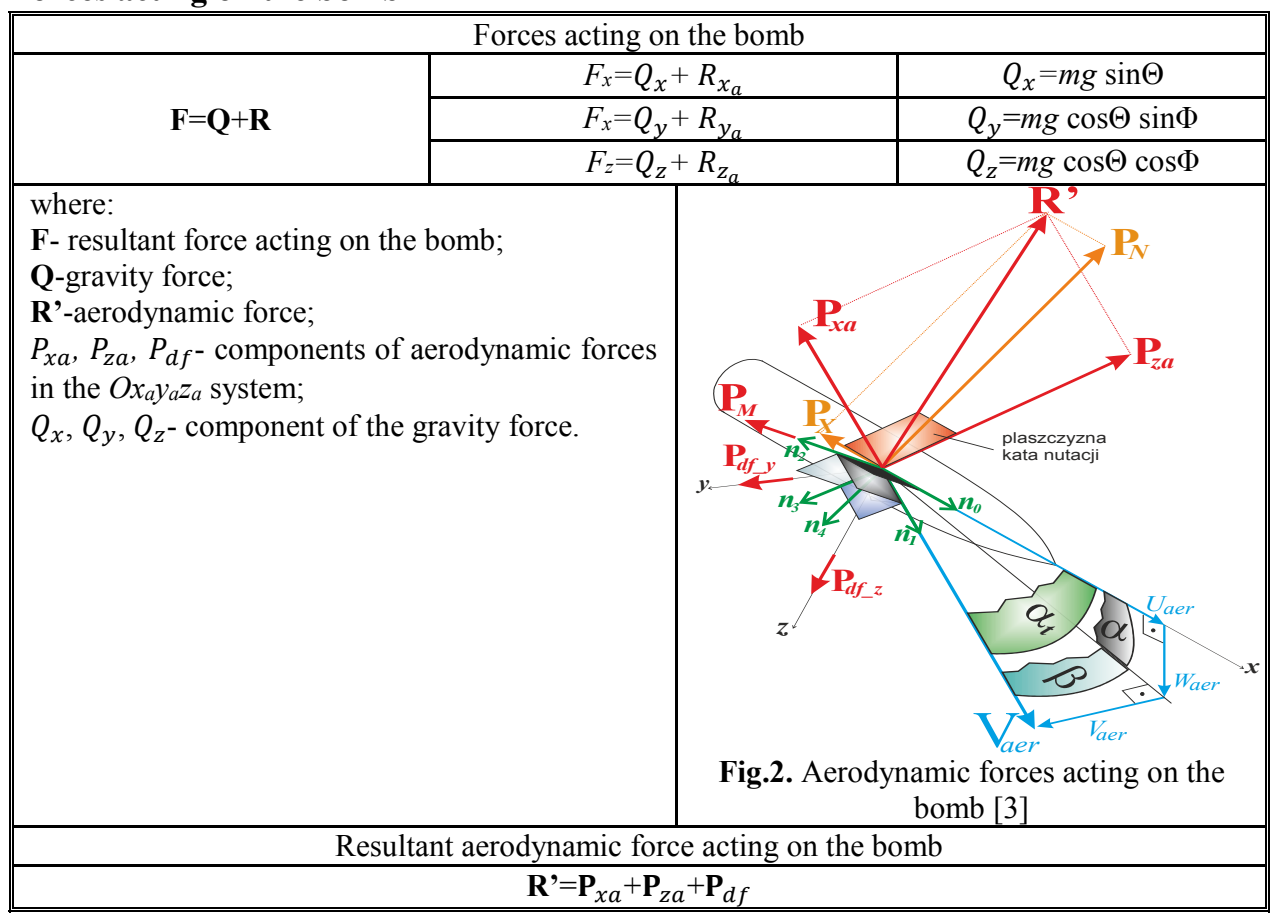




\begin{tabular}{|c|c|}
\hline $\mathbf{P}_{x a}=-P_{x a} \mathbf{n}_{1}$ & $P_{x a \_x}=-P_{x a} n_{l x,} \quad P_{x a \_y}=-P_{x a} n_{l y,} \quad P_{x a_{-} z}=-P_{x a} n_{l z}$ \\
\hline$P_{x a}=C_{x a} \frac{\rho\left|\mathbf{V}_{\text {aer }}\right|^{2}}{2} \mathrm{~S}$ & $C_{x a}=C_{x a 0}+C_{x a 2}\left(\sin \alpha_{t}\right)^{2}+C_{x a 4}\left(\sin \alpha_{t}\right)^{2}$ \\
\hline $\mathbf{P}_{z a}=-P_{z a} \mathbf{n}_{3}$ & $P_{z a \_x}=-P_{z a} n_{3 x}, \quad P_{z a \_y}=-P_{z a} n_{3 y}, \quad P_{z a \_z}=-P_{z a} n_{3 z}$ \\
\hline$P_{z a}=C_{z a} \frac{\rho\left|\mathbf{V}_{\mathrm{aer}}\right|^{2}}{2} \mathrm{~S}$ & $C_{z a}=C_{x a 2}\left(\sin \alpha_{t}\right)^{2}+C_{x a \alpha 3}\left(\sin \alpha_{t}\right)^{3}$ \\
\hline \multicolumn{2}{|r|}{$\mathbf{P}_{\mathrm{df}}=\left(C_{d f_{-} q}+C_{d f-\alpha_{t}}\right) \frac{\rho\left|\boldsymbol{V}_{a e r}\right|^{2}}{2} \mathrm{Sd}$} \\
\hline \multicolumn{2}{|r|}{ Unit vectors } \\
\hline $\mathbf{n}_{\mathbf{1}}=\left[n_{1 x}, n_{1 y}, n_{l z}\right] \quad n_{1 x}=\frac{U_{a e r}}{\mathbf{v}_{a e r}}$ & $n_{l z}=\frac{W_{a e r}}{\mathbf{V}_{a e r}}$ \\
\hline $\mathbf{n}_{3}=\left[n_{3 x}, n_{3 y}, n_{3 z}\right] \quad \mathbf{n}_{3}=\frac{\mathbf{n}_{1} \times \mathbf{n}_{2}}{\left|\mathbf{n}_{1} \times \mathbf{n}_{2}\right|}$ & $n_{3 x}=\frac{n_{1 x} \times n_{2 x}}{\left|n_{1 x} \times n_{2 x}\right|} \quad n_{3 x}=\frac{n_{1 y} \times n_{2 y}}{\left|n_{1 y} \times n_{2 y}\right|} \quad n_{3 x}=\frac{n_{1 z} \times n_{2 z}}{\left|n_{1 z} \times n_{2 z}\right|}$ \\
\hline $\mathbf{n}_{\mathbf{3}}=\left[n_{2 x}, n_{2 y}, n_{2 z}\right] \quad \mathbf{n}_{\mathbf{2}}=\frac{\mathbf{n}_{\mathbf{1}} \times \mathbf{n}_{\mathbf{0}}}{\left|\mathbf{n}_{\mathbf{1}} \times \mathbf{n}_{\mathbf{0}}\right|}$ & $n_{3 x}=\frac{n_{1 x} \times n_{0}}{\left|n_{1 x} \times n_{0}\right|} \quad n_{3 x}=\frac{n_{1 y} \times n_{0}}{\left|n_{1 y} \times n_{0}\right|} \quad n_{3 x}=\frac{n_{1 z} \times n_{0}}{\left|n_{1 z} \times n_{0}\right|}$ \\
\hline \multicolumn{2}{|c|}{ compatible with axis $O x$} \\
\hline $\begin{array}{l}\text { where: } \\
\mathbf{P}_{x a} \text {-force of aerodynamic drag; } \\
\mathbf{P}_{Y a} \text { thrust force; } \\
\mathbf{P}_{d f} \text {-aerodynamic damping force } \\
S \text {-cross-section of the bomb; }\end{array}$ & $\begin{array}{l}d \text {-diameter of the bomb; } \\
\rho \text { air density; } \\
C_{x a} \text { - coefficients of aerodynamic drag; } \\
C_{z a}-\text { coefficients of the aerodynamic lift; } \\
C_{d f_{f} q}, C_{d f-\alpha_{t}} \text {-coefficients of damping force depending } \\
\text { on the angle of roll } q \text { and nutation angle } \alpha_{t} . \\
\end{array}$ \\
\hline
\end{tabular}

Aerodynamic damping $\mathbf{P}_{d f}$ is generated when a bomb moves with an angular velocity of pitch $Q$ and yaw $R$. $\mathbf{P}_{d f}$ is a small force comparing to other forces and was omitted in further calculations. Figure 2 describes the location of aerodynamic forces acting on the bomb and nutation angle $\alpha_{t}$. This is the angle between the speed vector $V_{a e r}$ and the longitudinal axis of the bomb $O x[4]$.

\subsection{Moments of forces acting on the bomb}

Unchangeable location of the gravity centre of the bomb results in the fact that the bomb in flight is affected by aerodynamic moment $\mathbf{M}$. It includes static and dynamic moments [4]. A static moment is produced by the lack of revolution of the bomb and depends on the nutation angle $\alpha_{t}$ and Mach number Ma. Dynamic moments are produced when the bomb rotates with angular speed $\Omega$ [4].

\section{Moments of forces acting on the bomb}

Table 5

\begin{tabular}{|c|c|}
\hline \multicolumn{2}{|r|}{ Static moment } \\
\hline $\mathbf{M}_{\mathrm{st}}=M_{s t} \mathbf{n}_{2}$ & $M_{s t_{-} x}=0, \quad M_{s t_{-} y}=M_{s t} n_{2 y}, \quad M_{s t_{-} z}=M_{s t} n_{2 z}$ \\
\hline$M_{s t}=C_{m_{-} s t} \frac{\rho\left|\mathrm{V}_{\mathrm{aer}}\right|^{2}}{2} S d$ & $C_{m \_s t}=C_{m \alpha} \sin \alpha_{t}+C_{m \alpha 3}\left(\operatorname{si} \alpha_{t}\right)^{3}+C_{m \alpha 5}\left(\sin \alpha_{t}\right)^{5}$ \\
\hline $\begin{array}{l}\text { where: } \\
\mathbf{M}_{s t}-\text { pitching moment; } \\
C_{m \_s t}-\text { rolling moment coeffi } \\
d-\text { bomb diameter. }\end{array}$ & \\
\hline
\end{tabular}




\begin{tabular}{|c|c|}
\hline \multicolumn{2}{|c|}{ Dynamic moment } \\
\hline $\mathbf{M}_{d m}=M_{d m}\left(\mathbf{n} \times \frac{d \mathbf{n}}{d \mathrm{t}}\right)$ & $\begin{array}{c}M_{d m_{-} x}=0 \\
M_{d m_{-} y}=\left(C_{m_{-} q}+C_{m_{-} \dot{\alpha}}\right)\left(\frac{Q d}{\left|\mathbf{V}_{\text {aer }}\right|}\right) \frac{\rho\left|\mathbf{V}_{\text {aer }}\right|^{2}}{2} S d \\
M_{d m_{-} z}=\left(C_{m_{-} q}+C_{m_{-} \dot{\alpha}}\right)\left(\frac{R d}{\left|\mathbf{V}_{\text {aer }}\right|}\right) \frac{\rho\left|\mathbf{V}_{\text {aer }}\right|^{2}}{2} S d\end{array}$ \\
\hline $\mathbf{M}_{d m}=\left(C_{m_{-} q}+C_{m_{-} \dot{\alpha}}\right) \frac{\rho\left|\mathbf{V}_{\text {aer }}\right|^{2}}{2} S d$ & $C_{m \_q}=C_{m q 0}+C_{m \alpha 2}\left(\sin \alpha_{t}\right)^{2}+C_{m \alpha 4}\left(\sin \alpha_{t}\right)^{4}$ \\
\hline $\begin{array}{l}\text { where: } \\
\mathbf{M}_{d m^{-}} \text {pitch-damping moment; } \\
C_{m_{-} q}-\text { roll-damping moment coef } \\
C_{m_{\_} \dot{\alpha}}-\text { static pitching moment co }\end{array}$ & \\
\hline
\end{tabular}

\section{Model of the wind field described by Shinozuka}

The model of the wind turbulence was defined in publications [7, 8]. Below, an abbreviated description of Shinozuka model is exhibited.

According to this model, components of wind turbulence can be illustrated in the form of harmonic series with random parameters:

$$
\mathbf{V}_{\text {turb } \_}(\mathbf{r})=\sum_{j=1}^{i} \sum_{l=1}^{L}\left|H_{i j}\left(\boldsymbol{\Omega}_{l}\right)\right| \sqrt{2 \Delta \boldsymbol{\Omega}} \cos \left(\boldsymbol{\Omega}_{l}^{\prime} \mathbf{r}+\varphi_{j l}\right)
$$

where: $\mathbf{V}_{\text {turb_i }}(\mathbf{r})$ - $i$-this vector component of turbulence in the point, the location of which is defined by vector $\mathbf{r}=\left[x_{g}, y_{g}, z_{g}\right]^{T} ; H_{i j}$ - matrix elements $\mathbf{H}$ defining amplitudes of oscillation, $\boldsymbol{\Omega}_{l}=\left[\Omega_{l x}, \Omega_{l y}, \Omega_{l z}\right]^{T}$ - vector of 'spatial' frequency, $\boldsymbol{\Omega}_{l}^{\prime}$ - randomly disturbed vector $\boldsymbol{\Omega}_{l}$, $\varphi_{j l}$ - random oscillation phase.

Matrix $\mathbf{H}$ is associated with the matrix of power spectra density described by the following equation:

$$
\boldsymbol{\Phi}(\mathbf{\Omega})=\mathbf{H}(\mathbf{\Omega}) \cdot \mathbf{H}^{T}(\mathbf{\Omega})
$$

Power spectrum depends on the standard deviation of the wind $\sigma_{w}$ and the so-called turbulence scale $L_{w}$. Standard deviation is the basis for estimating the 'force' of the wind and is expressed in $[\mathrm{m} / \mathrm{s}]$, and turbulence scale describes the length $[\mathrm{m}]$, on which the gusts are correlated.

Based on the above mathematical equations describing the motion of a bomb in atmospheric turbulence and model of the wind field, the proprietary programme was written. It enables us to determine the parameters of the bomb flight. The programme is used to conduct simulation of the bomb's flight released with the adopted initial conditions such as: release altitude $H_{p}[\mathrm{~m}]$, release speed $V_{p}[\mathrm{~m} / \mathrm{s}]$, release angle $\Theta_{p}[\mathrm{deg}]$ and defining the turbulence intensity of the wind by providing standard deviation of the wind $\sigma_{w}[\mathrm{~m} / \mathrm{s}]$ and turbulence scale $L_{w}[\mathrm{~m}]$. 


\section{Parameters describing the bomb's flight}

By describing the movement on the flight path of the bomb, which was released in atmospheric turbulence, we determine:

- bomb's flight time T[s]. Determining the bomb's flight time enables to define initial limit parameters of bomb release, by which there is enough time to initiate flight correction system and include the made corrections of the flight trajectory;

- trajectory of the bomb's flight $X_{g d}[\mathrm{~m}], Y_{g o}[\mathrm{~m}]$. It enables to determine the range, yaw and gain in height, that the bomb reaches on the flight path;

- $\quad$ bomb speed on the flight path $\mathrm{V}[\mathrm{m} / \mathrm{s}]$. Knowing the ground speed of the bomb, it is possible to compute its impact energy. This value allows to determine the efficiency of target hit.

- $\quad$ angle of pitch of the bomb on the flight path $\Theta[\mathrm{deg}]$;

- $\quad$ angle of yaw of the bomb on the flight path $\Psi[\mathrm{deg}]$;

- angle of roll of the bomb on the flight path $\Phi[\mathrm{deg}]$.

The structure of the guided missile's detection system enables to observe the target located inside the cone with angle $15^{\circ}$ from the symmetry axis of the bomb. If we know the angles of pitch and yaw of the bomb during the bomb's flight, we can determine the field of view of detectors relative to the target. Ensuring the constant observation of the target by detectors in transition and terminal guidance of the bomb's flight affects the correct development of command signals. Trajectory of the guided bomb's flight from launch till release can be divided into 3 separate stages: ballistic, transition and terminal guidance (fig. 3) [9].

Ballistic phase occurs between the bomb and the point, where the bomb starts to receive reflected laser radiation. During this phase, ballistic characteristics of the released bomb are very similar to characteristics of a standard bomb for any release conditions (dive, ascending flight and level flight).

Transition phase occurs when the bomb detaches from the aircraft and receives laser radiation, and the point, where the image of spot is directed to the centre of quadrant.

Ultimate guidance phase occurs when the incompatibility angle of the bomb's axis with the aiming axis equals 1 degree. 


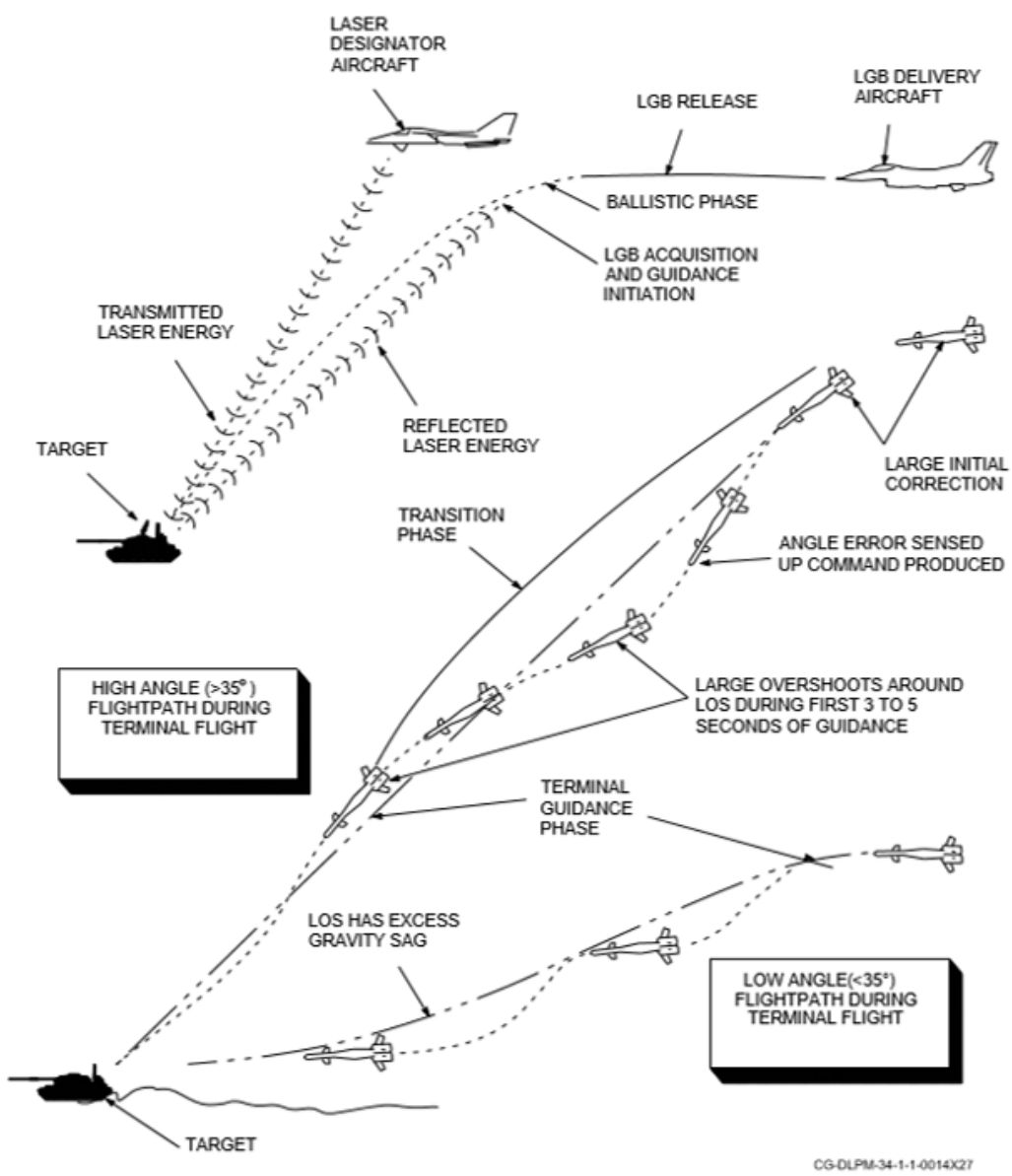

Fig. 3. Trajectory of flight of the guided bomb [9]

The fall angle of a bomb enables to adopt initial parameters of the release, which allow to reach high angle of impact. Releases with a high angle of impact are defined as releases, for which the impact angle is equal or higher than $35^{\circ}$. The flight trajectory for a drop of this type was illustrated in fig. 3. For such a drop method, axis deflection from the aiming line of the target is usually from 1 to $1,5 \mathrm{~m}$. Obtaining a high impact angle of the bomb enables the correct operation of the control system during flight. It guarantees the appropriate energy supply, which is necessary for the bomb to strike the target.

The angle of fall of the bomb, fall speed, shape of warhead, type of ground, are sufficient to determine, if, under the given release conditions, a ricochet of the bomb will occur. This knowledge has a substantial impact on safety during combat use of the investigated bomb. 


\section{Numerical example}

The study object is a small-diameter guided training bomb. The basic parameters of the bomb are as follows:

- length $850 \mathrm{~mm}$

- body diameter $109,7 \mathrm{~mm}$

- $\quad$ span of stabilizers $212 \mathrm{~mm}$

- mass $15,5 \mathrm{~kg}$

- $\quad$ guidance system laserowy

A bomb launch was simulated from the level flight $\Theta_{p}=0^{\circ}$, from altitude $H_{p}=3000 \mathrm{~m}$ and with the release speed of $V_{p}=55 \mathrm{~m} / \mathrm{s}$. Initial parameters were assumed taking into account the tactical and technical conditions of Mi-24 helicopter (which is a manned platform used for field tests) and enable to check the operation correctness of the studied bomb. The atmospheric turbulence modelled in a simulation programme defines 3 levels of the influence of standard deviation of the wind $\sigma_{w}$ on a bomb:

- negligible turbulence, standard deviation of the wind $\sigma_{w}=0,5 \mathrm{~m} / \mathrm{s}$ and turbulence scale $L_{w}=400 \mathrm{~m}$;

- moderate turbulence, standard deviation of the wind $\sigma_{w}=4 \mathrm{~m} / \mathrm{s}$ and turbulence scale $L_{w}=400 \mathrm{~m}$;

- severe turbulence, standard deviation of the wind $\sigma_{w}=12 \mathrm{~m} / \mathrm{s}$ and turbulence scale $L_{w}=400 \mathrm{~m}$;

Figures $4 \div 7$ illustrate wind components with standard deviation $\sigma_{w}=0,5 \mathrm{~m} / \mathrm{s}, 4 \mathrm{~m} / \mathrm{s}$ and $12 \mathrm{~m} / \mathrm{s}$. Turbulence scale remains constant and equals $L_{w}=400 \mathrm{~m}$.

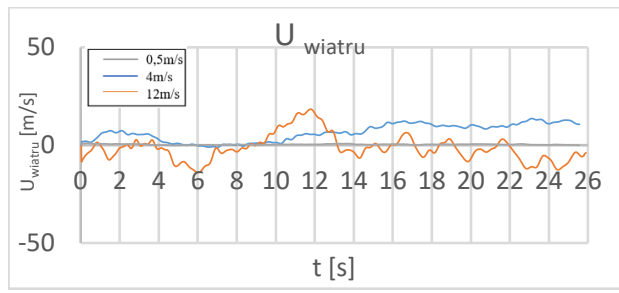

Fig. 4. Turbulence component $\mathrm{u}_{\text {wiatru }}(\mathrm{t})$ of the wind acting on the bomb during flight

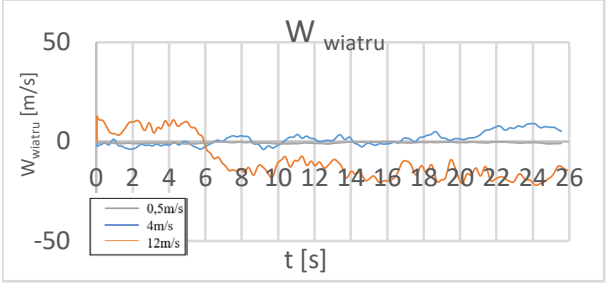

Fig. 6. Turbulence component $\mathrm{w}_{\text {wiatru }}(\mathrm{t})$ of the wind acting on the bomb during flight

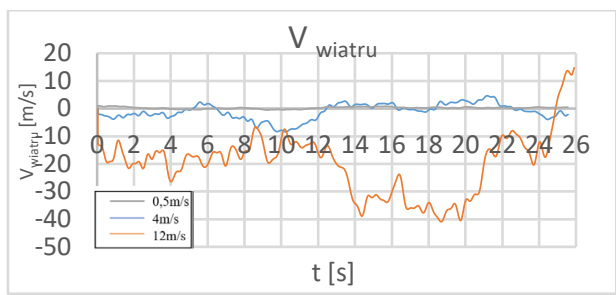

Fig. 5. Turbulence component $v_{\text {wiatru }}(t)$ of the wind acting on the bomb during flight 
Trajectory of the bomb's flight for the range and yaw was exhibited in figures. It was launched in atmospheric turbulence with the above mentioned turbulence components of the wind. Angles of pitch, roll and yaw of the bomb released in atmospheric turbulence were illustrated in figures $9 \div 11$.

The influence of the wind gusts on the bomb results in the change of nutation angle of the bomb that impacts the range of the bomb. The most significant change in the range of a bomb in relation to the read range for the bomb released in non-turbulent atmosphere was reported for $\sigma_{w}=12 \mathrm{~m} / \mathrm{s}$. This range decreased by $\Delta X_{g d}=58,92 \mathrm{~m}$ and amounted to $X_{\text {gd } 12}=1250,37 \mathrm{~m}$.

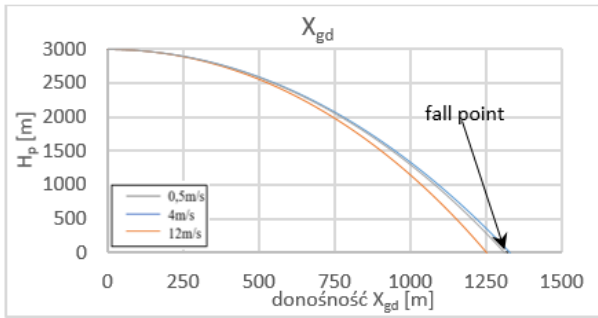

Fig. 7. Trajectory of the bomb's flight in the range function $\mathrm{X}_{\mathrm{gd}}$

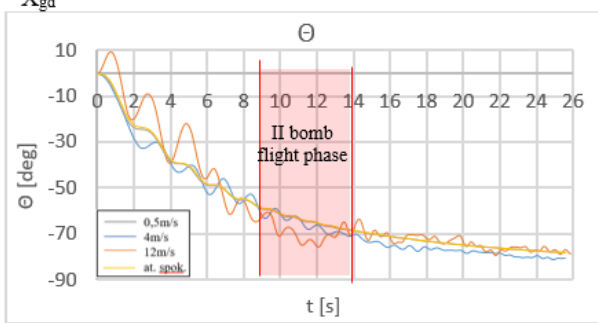

Fig. 9. Angle of pitch of the bomb $\Theta$

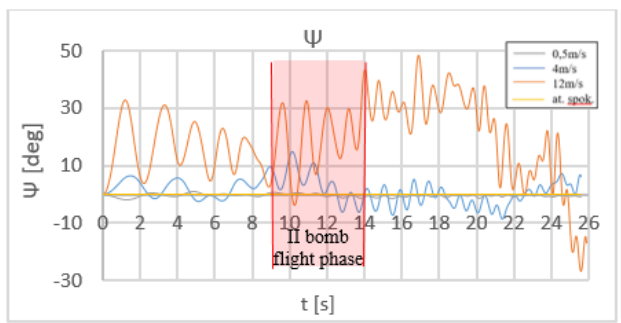

Fig. 11. Angle of yaw of the bomb $\Psi$

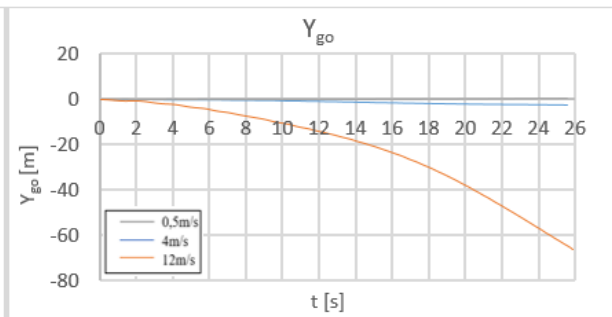

Fig. 8.Flight deflection of the bomb $Y_{g d}$ from aiming axis

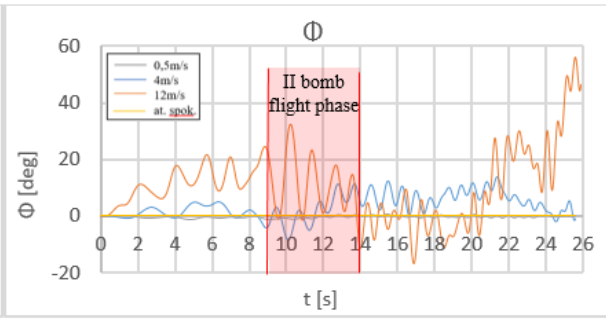

Fig. 10. Angle of roll of the bomb $\Phi$

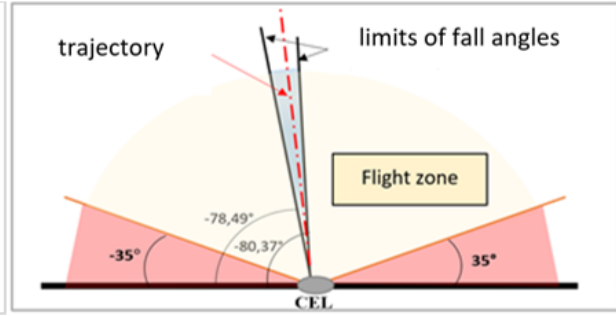

Fig.12.Flight zone of the bomb released with a high fall angle

The crosswind has an impact on the deflection degree from aiming line and is $\Delta Y_{\text {go o }, 5}=0,46 \mathrm{~m}$ for $\sigma_{w}=0,5 \mathrm{~m} / \mathrm{s}, \Delta Y_{g o}=-2,74 \mathrm{~m}$ for $\sigma_{w}=4 \mathrm{~m} / \mathrm{s}$ and $\Delta Y_{g o} 12=-66,5 \mathrm{~m}$ for $\sigma_{w}=12 \mathrm{~m} / \mathrm{s}$ respectively. The roll of the bomb relative to the symmetry axis is caused by the influence of wind components on control surfaces and stabilizers of the bomb. The change in the size of the angles of roll of the bomb during the flight was depicted in figure 10 . The maximum angles of roll of the bomb, released in atmospheric turbulence reached the following values: $\Delta \Phi=0,72^{\circ}$ for $\sigma_{w}=0,5 \mathrm{~m} / \mathrm{s}, \Delta \Phi=13,8^{\circ}$ for $\sigma_{w}=4 \mathrm{~m} / \mathrm{s}$ and $\Delta \Phi=55,9^{\circ}$ for 
$\sigma_{w}=12 \mathrm{~m} / \mathrm{s}$. The smallest fall angle of the bomb was reported for the standard deviation of the wind $\sigma_{w}=12 \mathrm{~m} / \mathrm{s}$ and was $\Theta_{u 12}=-80,37^{\circ}$, but the largest fall angle was detected for $\sigma_{w}=0,5 \mathrm{~m} / \mathrm{s}$, and it amounted to $\Theta_{u 0,5}=-78,49^{\circ}$. The obtained results show that the bomb was dropped in a way, which enables us to achieve a high angle of fall. The absolute value of the angle of fall of the bomb dropped in atmospheric turbulence equals $\geq 35^{\circ}$ (fig. 12 ). In the case under consideration, the angle of pitch of the bomb released in atmospheric turbulence in the second half of the flight, that is from $t=13 \mathrm{~s}$ of the flight, is close to the angle obtained during the release in non-turbulent atmosphere. The maximum difference between these angles was $\Delta \Theta=0,48^{\circ}$ for $\sigma_{w}=0,5 \mathrm{~m} / \mathrm{s}, \Delta \Theta=4,57^{\circ}$ for $\sigma_{w}=4 \mathrm{~m} / \mathrm{s}$ and $\Delta \Theta=5,79^{\circ}$ for $\sigma_{w}=12 \mathrm{~m} / \mathrm{s}$. The angle of yaw of the bomb from an aiming line attained the maximum value $\Delta \Psi=48,3^{\circ}$ for $\sigma_{w}=12 \mathrm{~m} / \mathrm{s}$, and by the standard deviation of the wind $\sigma_{w}=0,5 \mathrm{~m} / \mathrm{s}$, this angle amounted to $\Delta \Psi=1,07^{\circ}$. Taking into account the three phases of the bomb's flight, it is possible to determine the moment of the bomb's entry in the transition phase. This phase should last approx. $3 \div 5 \mathrm{~s}$. During this phase, the illuminated target is intercepted by the bomb's detectors. Bomb's entry into the transition phase depends on the distance, from which the detectors identify the target and observation angles of the target by detectors. In the investigated case, this phase begins between $9 \div 14$ s (fig. $9 \div 11$ ). If it is met, then the angles of roll, pitch and yaw reach the values enabling the interception of the illuminated target by detectors and initiation of the control system. The distance of the bomb from the target during this flight phase provides a sufficient power of reflected laser ray, which is essential for the correct operation of the detection system.

\section{Conclusions}

Turbulence components $u_{\text {wiatru }}, v_{\text {wiatru }}, w_{\text {wiatru }}$ have an impact on the behaviour of the bomb during the flight. A direct influence of the wind results in changes in the nutation angle of the bomb $\alpha_{t}$, which contributes to shortening its range. A deflection of the bomb's flight path from the aiming line is due to the effect of the component of crosswind $v_{\text {wiatru }}$. The largest deviation of the fall point of the bomb released in atmospheric turbulence from the fall point obtained in a non-turbulent atmosphere was reported for the largest standard deviation of the wind. The diagrams showing the change in the angle of pitch, roll and yaw indicate that along with the increase in the standard deviation of the wind, the difference between the angles obtained for the bomb released in atmospheric turbulence and the angles measured for the bomb released in non-turbulent atmosphere increases as well. If we know the values of the angles of pitch, roll, yaw and trajectory of the bomb's flight as well, we can calculate the time when the transition to the second flight phase occurs. Providing we have the angle of fall of the bomb $\Theta$, travelling in atmospheric turbulence, it is possible to evaluate the probability of the bomb's ricochet and establish initial parameters of the release, which are indispensable to obtain a high angle of fall of the bomb. 


\section{References}

1. Długołęcki A., Buler W., Faryński A., Winczura Z.: Sprawozdanie z pracy statutowej Opracowanie koncepcji modułowej konstrukcji rodziny bomb o wagomiarze 100, 250 i $500 \mathrm{~kg}$. Unpublished, ITWL, Warszawa 2016.

2. Gacek J.: Balistyka zewnętrzna, cz. I Modelowanie zjawisk balistyki zewnętrznej i dynamiki lotu. Wydawnictwo WAT, Warszawa 1999.

3. Gacek J.: Balistyka zewnętrzna, cz. II Analiza dynamicznych właściwości obiektów w locie. Wydawnictwo WAT, Warszawa 1999.

4. Kowaleczko G.: Modelowanie dynamiki lotu obiektów latających. Wydawnictwo ITWL, Warszawa 2018.

5. Kowaleczko G., Pietraszek M., Grajewski K.: Model dynamiki zrzutu bomby w warunkach turbulencji. Wyd. WITU, z. 146, nr 2, 2018.

6. Kowaleczko G., Buler W., Pietraszek M., Grajewski K.: Model ruchu sterowanej bomby lotniczej w warunkach turbulencji. Wyd. PTMTS Mechanika w lotnictwie ML-XVIII, tom I, Warszawa 2018.

7. Kowaleczko G., Kaźmierczak R.: Influence of the atmospheric turbulence on the accuracy of the missile targeting. Journal of KONES, Vol. 24, No. 1, 2017.

8. Mnitowski S.: Modelowanie lotu samolotu w burzowej atmosferze. Phd thesis, WAT, Warszawa 2006.

9. Pietraszek M.: Modelowanie i symulacja dynamiki ruchu bomby kierowanej, ITWL Warszawa 2019. 